\title{
COMPARING THE USE OF DIGITAL PLATFORMS IN TOURISM Tatiana Genzorová $^{1}$, Tatiana Čorejová ${ }^{2}$, Natália Stalmašeková ${ }^{3}$
}

\begin{abstract}
People today are more willing to spend money on travel than ever before. Because of new possibilities, traveling is easier and travelers can choose options quicker for immediate travel. Today, their decisions are influenced by the use of mobile applications in tourism, which can help with finding accommodation the world over. Travelers do not need to check special hotels in a chosen destination and compare prices to find the most suitable or cheapest option. Mobile applications in tourism can do that for them, making traveling much simpler. The aim of this paper is to describe trends in tourism in Slovakia. The first part of the paper contains a general framework of digital platforms and the second part describes the current situation of tourism in Slovakia compared with that in the Czech Republic. The paper highlights attitudinal differences between countries regarding the use of mobile applications in tourism. The final part of the paper contains research about new customs of Slovaks in tourism.
\end{abstract}

JEL Classification Numbers: L83; DOI: http://dx.doi.org/10.12955/cbup.v6.1148

Keywords: tourism, mobile applications, comparison, digital platform, traveling.

\section{Introduction}

Tourism is fast becoming more popular and a part of everyday life. Although one may not see it directly, during the holiday season, tourism is flourishing and on weekends or working days people are traveling for work, relaxation, or fun. Today, there are hundreds of mobile applications dedicated to tourism and, similar to other areas, tourism prospers from the use of modern technology and advances in the digital world.

\section{Digital Platforms}

Digital platforms are described in Managing Digital Enterprise by Jun Xu (2014), who summarizes the attitudes of several authors, including Van Al Styne, Gimpel, and Westerman, as the first to openly describe the characteristics of digital platforms in the period 2012-2013.

Digital platforms are collectively understood as multilateral marketplaces designed to provide an interface for participants, such as producers, users (customers), and other third-party service providers to network and create collaborative outcomes. They have these basic characteristics:

1. Operate a double-sided effect - each party can be both a provider and a customer. This means that the user of the digital platform can either provide a service. For example, a smartphone user might need to travel from point A to point B. They choose a route from Dresden to Prague and as a customer use one of the digital platforms, hypothetically 'BlaBlaCar', which is available in both areas. The user enters the start and exit of the journey into the mobile application and the mobile application looks for the closest ride at the time required by the user to travel to their destination. Another user of the app at the same time might be driving with a free place in their vehicle and as a provider offers to take the first user to their destination for a specific payment. Next time, users change their roles in the process. The user who searched for a ride before can provide a ride for users and the user who provided the ride before can searched for ride.

2. Offer interaction between stakeholders with regulations, standards, but especially internal rules of the digital platform, regulating user behavior; and

3. Reduce users search cost and easily create value.

To understand the functioning of the digital platform, it is important to explain who plays which role and the value of each participant in the given model.

\footnotetext{
${ }^{1}$ University of Žilina, Faculty of Operation and Economics of Transport and Communications, Žilina, tatiana.genzorova@gmail.com

${ }^{2}$ University of Žilina, Faculty of Operation and Economics of Transport and Communications, Žilina, tatiana.corejova@uniza.sk

${ }^{3}$ University of Žilina, Faculty of Operation and Economics of Transport and Communications, Žilina, natalia.stalmasekova@fpedas.uniza.sk.
} 


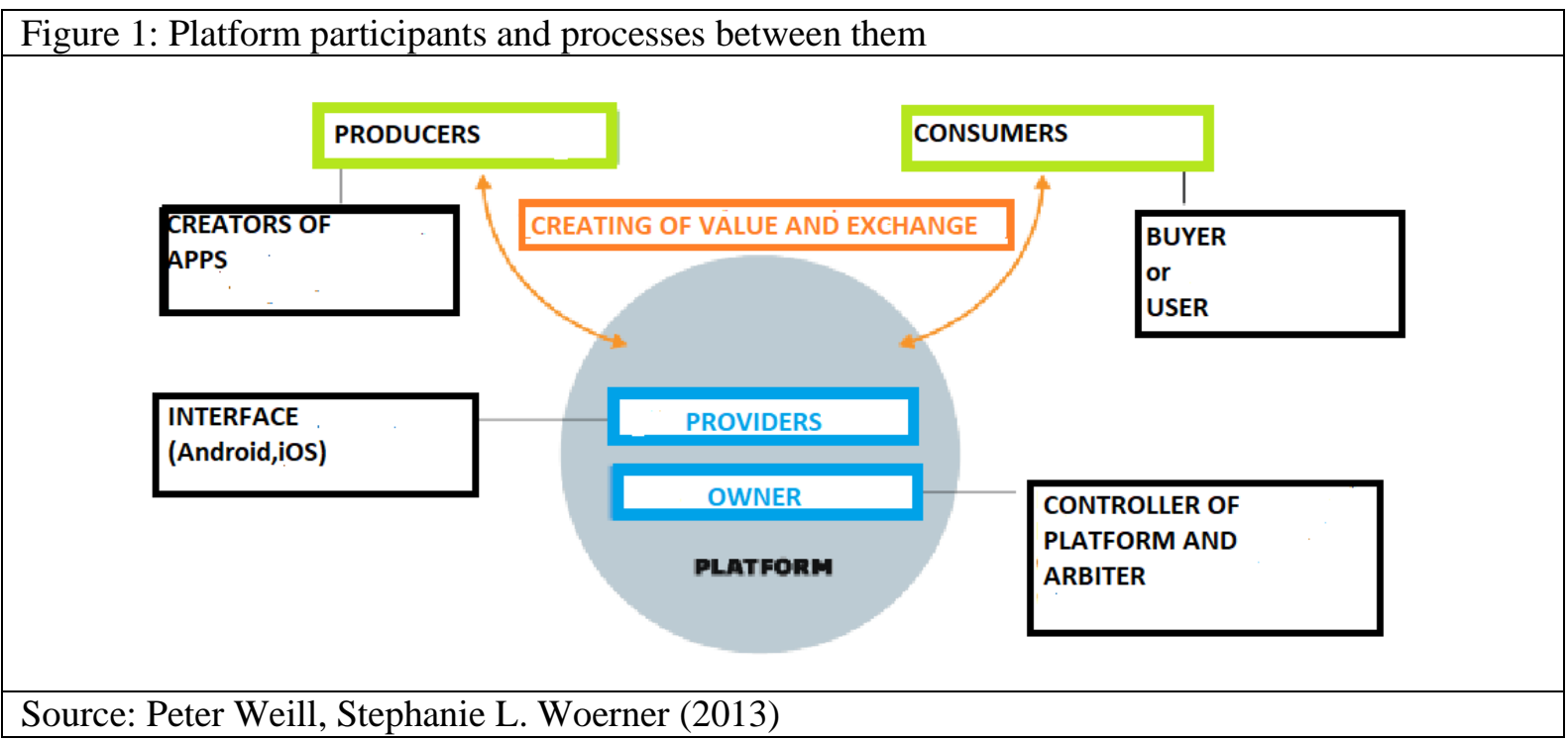

Figure 1 shows the key participants of a standard digital platform. When creating value, there is a meeting of these crucial parties:

- The owner of the platform - usually companies in the private sector. The owner of the platform is responsible for developing and managing the platform. An example is Apple and Google that offer their platforms as the App Store and the Google Play mobile app manufacturers to sell their services that support the platform;

- Users and consumers - individuals, communities, or business entities that use the value provided by the platform. The end user will download the mobile app using the respective app store, which uses its platform to provide developer services.

- Manufacturer and producers - create offers that they sell using a chosen platform. For example, app creators sell their products using Google Play or App Store.

- Provider - role is to provide a platform interface. For example, mobile phone manufacturers.

Another part of the platform constitutes other interested parties. The first large group involves partners in the development, the capital formation of a company that can significantly influence the emergence of the platform ecosystem.

Other stakeholders also include a part of the public sector that understands the benefit of developing the platform for public welfare, as well as the various regulators of states that recognize any unlawfulness within the business.

Regarding digital platforms, the question of modularity arises where it is possible in digital content applications as well as in their distribution. By making the digital platforms easy to obtain, they can be part of multiple mobile devices, networks, and part of the operating system platforms.

A digital platform creates value when producers interact with consumers. The platform provides open, participatory infrastructure for these interactions and sets out the conditions for their management.

The main purpose of a platform is to allow trade between users and to facilitate the exchange of goods, services, or social value, allowing for value creation for all participants. The platforms create value in the community, and thus, people use it. Platforms can circumvent business rules, soften firm business boundaries, and transform the business of internal processes.

\section{Current Situation in Tourism}

Slovakia is striving to advance in the area of tourism. Service providers in this field use a variety of mobile apps to support tourism development. There are currently numerous mobile apps to help people search for accommodation, restaurants, and attractions. With some applications, there is an option to rate venues. The benefits of these apps include reviews by genuine customers who visit these destinations.

The company TNS Slovakia conducted a mobile application survey in 2015. Part of the survey examined how Slovaks use mobile applications. The results of this survey revealed that two-thirds of the respondents used mobile apps daily. Also, $80 \%$ of the respondents used mobile applications as social 
networks, $78 \%$ used them to simplify everyday life (e.g., navigation, wage calculation, and planning). More than $70 \%$ of respondents used apps to watch videos, listen to music, or for bank transactions, and $68 \%$ used the mobile apps to search for information (e.g., weather, trains, and hotels). More than 50\% of respondents used them as a news portal, or to edit and view photos, or otherwise in the field of education (e.g., dictionaries and self-taught languages) or healthy lifestyles.

According to Free Apps (FreeApps.me) there are 20 best hotel booking apps for iOS and Android (Table 1).

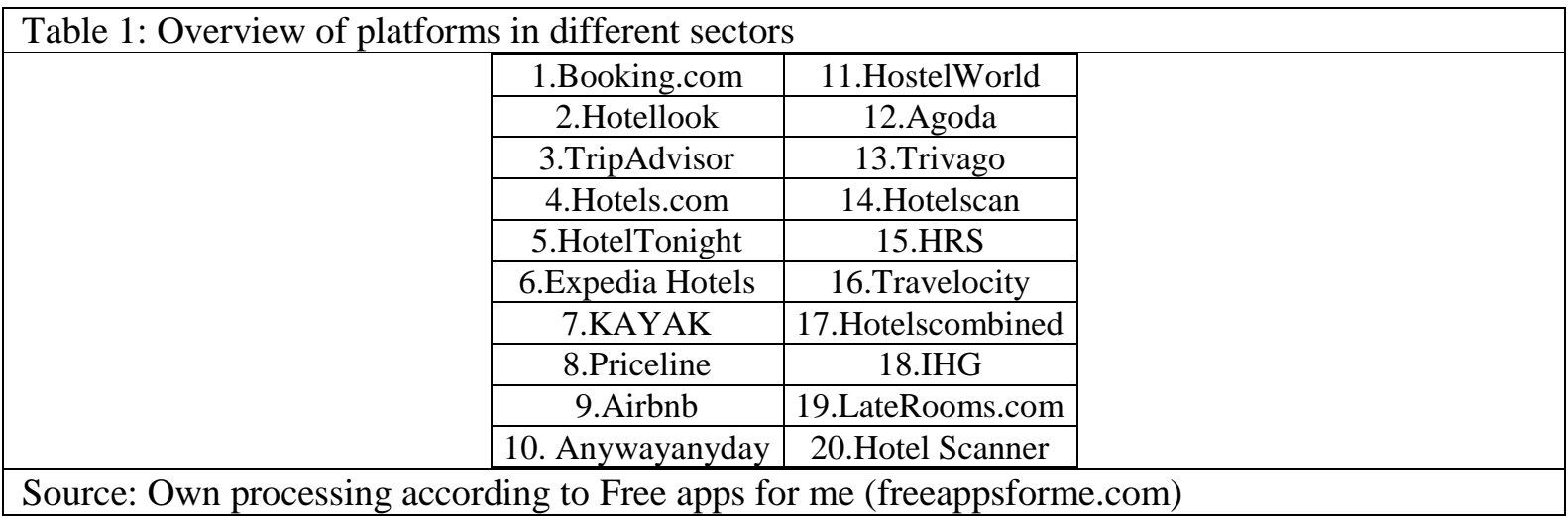

Table 1 shows the most used applications at present for searching and booking accommodation worldwide.

\section{Data and Methodology}

The aim of this research was to compare to selected surveys about the behavior of customers in tourism, i.e., as travelers. The assumption was that people who use mobile apps for tourism, mainly search for accommodation. The main research data were taken from Paterková (2017) involving surveys conducted in April 2017 and the number of completed questionnaires 196.

The data of Medovičová (2017) were used to compare Slovakia and Czech Republic in the use of mobile apps for tourism. These data were taken from surveys conducted in 2017 in the Czech Republic and involved 221 completed questionnaires.

\section{Results and Discussion}

The data from the research of Paterková (2017) show that $43.01 \%$ of their respondents used mobile apps to search for a stay of 1-2 nights at a selected accommodation (Figure 2). This was mostly for business trips. The most frequent response to this question about the length of stay searched for using mobile apps was a stay of 3-4 nights (48.39\%), which was primarily for leisure trips or vacations.

\begin{tabular}{|l|l|l|l|}
\hline Figure 2: The number of nights stay searched for using mobile apps \\
\hline
\end{tabular}

\section{Comparison of Slovakia and Czech Republic}

The surveys conducted by Paterková (2017) in Slovakia and that of Medovičová (2017) in the Czech Republic revealed some differences. First, 50\% of Slovak respondents claimed they used mobile apps for booking accommodation, whereas for Czech Republic respondents this figure was $77 \%$. 
Second, the mobile applications that respondents used differed between countries. Table 2 shows the five most-used applications for searching and booking accommodation for each, Slovakia and the Czech Republic. Although the surveys conducted in 2017 show that respondents from Slovak and Czech Republic picked Booking (booking.com) to search for accommodation, the Czech respondents appeared more open as travelers with results showing a preference for Couchsurfing, a platform for overnight stays on a provider's couch, free of charge, on the condition that the user provides a couch free of charge for another user of the platform.

Table 2: The most used mobile applications for accommodation.

\begin{tabular}{|c|c|}
\hline SLOVAKIA & CZECH REPUBLIC \\
\hline 1.Booking & 1.Booking \\
\hline 2.Trivago & 2.Airbnb \\
\hline 3.Airbnb & 3.Couchsurfing \\
\hline 4.Hotels.com & 4.Trivago \\
\hline 5.TripAdvisor & 5.TripAdvisor \\
\hline
\end{tabular}

Source: Own processing according to Paterková (2017) and Medovičová (2017)

\section{Conclusion}

The results of this research revealed certain trends in tourism. First, travelers are willing to use mobile apps to search for information about their journey. Based on survey responses, people use mobile apps to search for vacations and, most often, the most searched for destinations of the respondents were Slovakia, the Czech Republic, and Croatia, and the average amount they would pay per night was up to EUR 30. Mobile apps used to search for accommodation contain extensive venue information that can help potential customers decide on where to stay. Finally, respondents considered mobile applications gave them the advantage of choosing criteria that were important for them in choosing their accommodation.

\section{References}

Alstyne, M. W., Parker G.G., Choudary, S.P. (2016). In Pipelines, Platforms, and the New Rules of Strategy. Harvard Business Review, Retrieved from https://hbr.org/2016/04/pipelines-platforms-and-the-newrules-of-strategy

Alstyne, M. W., Parker G.G., Choudary, S.P. (2016). Platform revolution. New York:W.W. Norton \& Company Ltd.

Čorejová, T.\& Genzorová, T., Stalmašeková, N. Digital platform in tourism. In: Proceedings of the MARKETING IDENTITY Online rules - part II., Smolenice, Slovak Republic.Pp 41-49.

Holbusova, J. (2017) Aplikace pro mobilní zaříženi a jejich využitá v cestovním ruchu. Bachelor thesis.Retrieved from https://vskp.vse.cz/id/1246948

Jose, T. (2017). What is digital economy? Indian Economy.net, Retrieved from https://vskp.vse.cz/id/1246948https://www.indianeconomy.net/splclassroom/what-is-digital-economy/ Jun,X.(2014). Managing Digital Enterprise. Atlantis Press

Paterková (2017). Trendy využívania digitálnych platforiem v cestovnom ruchu. Bachelor thesis.

Reillier, L.C., Reillier, B. (2017). Platform strategy. New York: Routledge

Skiltom, M. (2016). Building Digital Ecosystem Architectures. New York: Palgrave Macmillan

TNS Slovakia, s.r.o. (2015) Mobilné aplikácie. Bratislava: TNS Slovakia

20 Best hotel booking apps for iOS \& Android (10 April 2018) Retrieved from https://freeappsforme.com/hotel-bookingapps-ios-android/ 